The next logical step in alliance

evolution may be for firms to focus

even more on participation with partners and less on retaining the right to forward integrate.

who want control of sales, as well as an investment community that historically has valued operating income far more than royalties.

Given the accelerating trend toward deintegration, one might ask whether this perception is still appropriate. If bottom-line return on investment is what really matters, an increasingly deintegrated industry that values efficiency first and foremost may suggest otherwise. Biotechnology companies might optimize their return on investment and efficiency by focusing their efforts, capital, and alliance strategies where they add the most valuesuch as on drug discovery and preclinical development-and not on the creation of redundant infrastructure.

We are beginning to see alliances by the gene-sequencing companies in which their role is more focused on research and preclinical development. In Human Genome Science's (HGS, Rockville, MD) 1993 alliance with SmithKline Beecham (SKB, Philadelphia, PA), for example, SKB agreed to pay up to $\$ 63$ million in license and milestone fees, plus up to an additional $\$ 62$ million in equity at extremely high premiums, in exchange for broad rights to manufacture and market products developed by HGS. However, even HGS retained rights to copromote products in North America by providing up to 20 percent of the total promotion effort, and it remains to be seen what HGS' ultimate strategy will be.

The evolution from "selling off" product rights to finance an integrated business toward bootstrapping greater participation into integrated capabilities has been a quite natural one. The next logical step in this evolution, given the current market dynamic, may be for companies to focus even more on participation with partners and less on retaining the right to forward integrate. Some companies might even find their optimal roles based on a pure research-and-development model.

In the early 1980 s, Alza (Palo Alto, CA) pioneered a revolutionary new business model for the pharmaceutical industry - what is now regarded as the "drug-delivery model"by focusing on development and licensing. While there were many early skeptics, Alza succeeded and created a lot of value along the way. By focusing their alliance strategies on leveraging existing infrastructures, rather than on replicating them, biotechnology companies may well be able to forge new business models of their own.

\title{
U.K. biotech will boom over next few years
}

The total OXFORD-U.K. biotechnology is set to boom, according to a recent report by accountants Arthur Andersen (AA, London), who surveyed top management at 166 U.K. biotech start ups. Indeed, the report states that the total turnover of these 166 firms will soon double, rising from $\$ 627$ million in 1992 to $\$ 1.3$ billion in 1996. Yet these firms are still a long way from turning an overall profit, as their aggregate pretax losses totalled $\$ 102$ million in 1992.

million in 1992

to $\$ 1.3$ billion in

1996. over the same time frame, from $\$ 198$ million in 1993 to $\$ 327$ million in 1996. The U.K. sector, of course, will be led by its flagship firms, including British Bio-technology (Oxford), Celltech (Slough), Cantab Pharmaceuticals (Cambridge), and Xenova (Slough).

AA, furthermore, expects consolidation within the U.K. sector. "The overwhelming majority of survey respondents expect acquisition or merger activity between U.K. biotech companies and large pharmaceutical companies to be a key feature of the sector over the next ten years," says Vernon Spencer, the author of the AA report. The need to obtain capital will be the driving force behind this consolidation, Spencer adds.

The 37 U.K. biopharmaceutical firms will continue to experience strong growth. Their aggregate turnover grew 20 percent, from $\$ 157$ million in 1992 to $\$ 287$ million in 1993, with the lion's share of revenues coming from contract R\&D and laboratory-reagent sales. Yet the aggregate pre-tax losses of these firms totalled $\$ 72$ million in 1993 , as just 22 percent of the companies registered profits before taxes. The first therapeutics emerging from these firms should reach the market near the end of 1995 or the beginning of 1996, believes AA. It also expects their total $R \& D$ spending to leap 68 percent, from $\$ 137$ million in 1993 to $\$ 230$ million by 1996 .

The 41 U.K. diagnostics companies will also show strong growth. Their total turnover will grow 78 percent, from $\$ 165$ million in 1993 to $\$ 294$ million in 1996 . The aggregate pre-tax losses of these firms, though, stood at \$18 million in 1993 , with just eight companies reporting pre-tax profits. Nonetheless, their aggregate $R \& D$ spending will rise by 70 percent, from $\$ 30$ million in 1993 to $\$ 51$ million in 1996.

And robust growth is expected for the U.K.'s 22 agbiotech firms, with their aggregate turnover soaring 274 percent, from $\$ 47$ million in 1993 to $\$ 174$ million in 1996 . These firms, though, tallied aggregate pre-tax losses of $\$ 5$ million in 1993. AA points out that while 75 percent of total turnover for these firms currently comes from product sales, though none of these products are recombinant ones, this portion is expected to rise to 95 percent by 1996. "This growth will, in part, arise from the segment's sales and distribution networks being significantly extended over the next three years through strategic alliances with partners who already have the necessary infrastructure in place," says Spencer.

—Mike Ward 